\title{
Leadership Mentoring Needed!
}

i Necesitamos tutoría en liderazgo!

Precisamos de assessoria em liderança!

Ellen B. Buckner

KEYWORDS (SOURCE: DeCS)

Leadership; cultural competency; organization and administration; mentoring; nursing.

PALABRAS CLAVE (FUENTE: DeCS)

Liderazgo; competencia cultural; organización y administración; tutoría; enfermería.

PALAVRAS-CHAVE (Fonte: DeCS)

Liderança; competência cultural; organização e administração; tutoria; enfermagem.

DOI: 10.5294/aqui.2019.19.4.1

Para citar este editorial / To reference this editorial / Para citar este editorial

Buckner EB. Leadership Mentoring Needed! Aquichan. 2019;19(4):e1941. DOI: https://doi.org/10.5294/aqui.2019.19.4.1

1 https://orcid.org/0000-0001-9676-2445. Samford University, USA. ellen.buckner@samford.edu 
Leadership mentoring is valuable! It is built on the richness of our nursing experience, the depth of our relationships, and the breadth of our nursing presence. It exercises our engagement, expands our scholarship, refines our passion, and ignites the next generation of nurse leaders. Leadership mentoring requires the selfless giving of our time and insight while encouraging us to be open to a new generation of nurses and nursing vision. In addition, leadership mentoring provides us with opportunities for advocacy for our profession and its worldwide mission.

Leadership mentoring in nursing can take many forms. It can be as informal as those moments when a simple hallway conversation encourages or inspires a colleague. It can be a formal program that engages scholars, frontline practicing nurses, or global acquaintances in planned activities for leadership development. Leadership mentoring challenges nurses to create and implement a vision of nursing excellence. What is that vision and how can it be enacted? Leadership mentoring helps nascent researchers to frontline clinicians envision change outside of their current role or "comfort zone." New leadership then catalyzes growth in nursing education, administration, and practice.

So, what are leadership mentoring attributes? Hodgson and Scanlon (1) conducted a concept analysis of mentoring for nursing leadership and found defining attributes of mentoring to include a relationship between two individuals with differing levels of experience, based on mutual respect and common goals, with a willingness by mentor and mentee to engage in the relationship, and sharing of knowledge. Cardiff and colleagues (2) utilized a person-centered leadership approach that included reflection, leading/evaluating a leadership practice change, and developing insight into leadership development. Cardiff and colleagues' attributes were being person-centered and authentically other-centered and caring. They found self-awareness emerged from reflections and that being open, patient and optimistic fostered a sense of tranquility as leaders listened and supported mentees' progress toward goals. Additional characteristics were awareness of context and presence in the participants. Thus, an essential criterion was to be engaged in a responsive relationship.

Formal mentoring programs are available through the International Council of Nurses (ICN), Sigma Theta Tau International (Sigma), and others, but most of these are for a short to intermediate term and face-to-face format, limiting accessibility. Morin and colleagues (3) evaluated 100 dyads from the Maternal
Child Leadership Academy (Sigma) and found enhanced leadership skills and behaviors, with additional needs to develop mentoring skills as a primary finding.

I was an unlikely convert to the significance of leadership mentoring. As a young or even mid-career nurse, I would have said leadership is an innate trait not a learned skillset. However, through the transformational experience of several leadership programs, I have discovered leadership mentoring as the most meaningful and authentic role I have held in nursing. Through it, I have found my calling. Participation in three Sigma Leadership Academies led me to understand more fully the significance of a formal structure, organizational context, team-focused methodology, and tangible outcomes-facilitated leadership growth.

In 2012, following the initiation of Global Regions in Sigma, several of us, including Dr. Nelly Garzón from Colombia, began a discussion on Global Nursing Leadership (4). That discussion led to the formation of the Global Leadership Mentoring Community, a Sigma Community of Interest $(5,6)$. Now beginning its third cohort, we have realized mentoring relationships across nursing education, leadership, and scholarship. We have connected across 16 time zones using freely available technology. Mentors have included former Aquichan editor Dr. Maria Elisa Moreno Fergusson from Colombia, and global nurse leaders from Australia, Hong Kong, Philippines, England, the Netherlands, South Africa, Pakistan, the USA and others. Outcomes have included growth in Sigma chapter leadership, participation in Biennial Convention, manuscript preparation, and the formation of new and lasting friendships.

In the most recent Sigma Biennial Convention, mentors and mentees met for the first time, and one example of shared joy was the beautiful Pakistani Shalwar Kameez brought to her mentor, Beth Chiatti, by mentee Salima Farooq (Figure 1). Through technology, community can be created across seemingly impossible expanse of geographic distance and time (Figure 2). Through these professional conversations and gifts of the heart, a community was formed.

In 2019, we began another journey of leadership mentoring and while it is still a fledgling venture, the potential for influencing nurses and nursing leadership is there. This group began as part of the Roy Adaptation Association International (RAA-I) with mentors and mentees from Colombia, Mexico, and several states in the USA, with potential to include others. We connect as Roy 
Scholars while developing goals such as contributing to RAA-I leadership through peer-review for journals, consultations, next generation presentations on the Roy Adaptation Model, and more. Mentoring mentors is part of the skill I have learned, and while not yet fully established, it is a significant part of any mentoring community. Likewise, mentees express a need for getting to know other mentees, having mentoring conversations even if no formal agenda, and collaborating together to set goals and plans. Thus, part of the format is conducting group calls for mentors and for mentees along the way.

Figure 1. Beth Chiatti (Mentor, USA) wears a Pakistani Shalwar Kameez brought by mentee Salima Farooq (Pakistan).

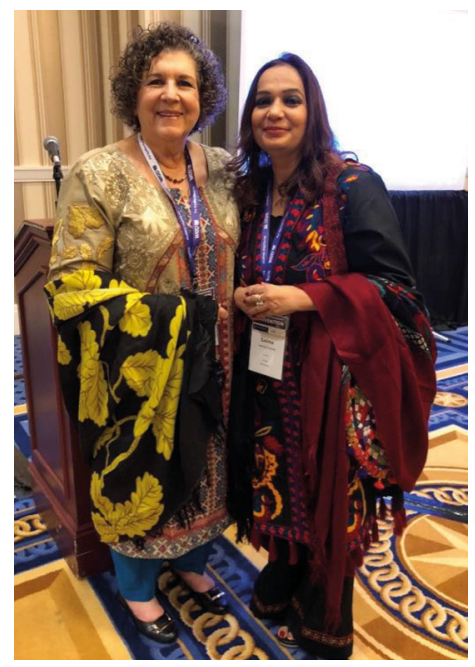

Source: Author's photo.

Figure 2. Global Leadership Mentoring Community (GLMC2) meets on a video conference across 16 time zones.

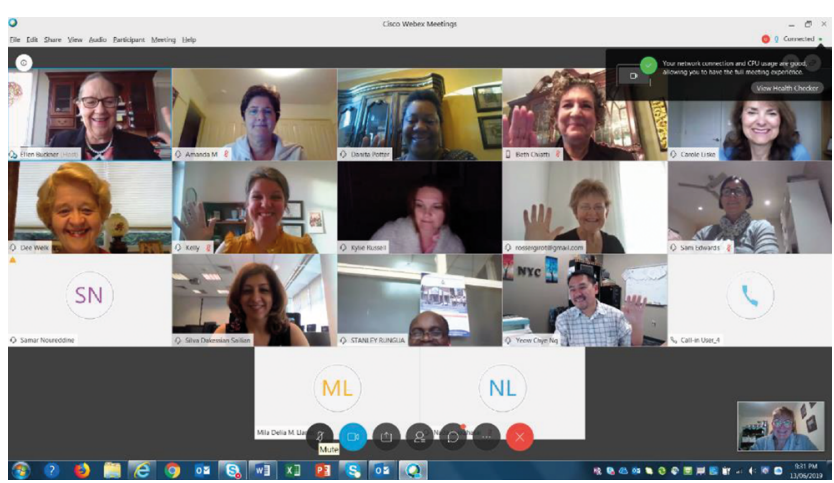

Source: Author's screenshot.
The formal structure of leadership mentoring which I experienced and have used in developing new programs was the cohort approach with a beginning, middle, conclusion, and committed relationships during the journey. The team-focused method encouraged the mentee to create a team at his/her home base, with team development at the core of leadership development. The organizational context—such as Sigma or the Roy Adaptation Association-was the structure for enacting new leadership skills. The tangible outcome, while a driving passion for the mentee, was also the vehicle for building their leadership skills. Outcome development fueled leadership growth. Benefits to mentees are support for problem solving in organizational roles, encouragement to take the next step in education, reviewing/editing a manuscript to improve a scholarly work, and collaboration through sharing of interests and expertise. Benefits for mentors are rewards of forming new relationships in nursing, applying their lifetime experience to support learning and professional growth, and seeing the mentees reach their goals.

Why is this so transformative? The continuity and influence brought to the relationship empowers the mentee to lead change and grow in their own context. The role of the mentor is not to answer questions but help the mentee seek out who to ask and how. The investment of time in a mentee and his/her work is returned multiple times as the mentor grows, learns skills of team development, applies concepts of leadership, and strengthens his/her own philosophy in making a difference. The formal, structured approach makes it possible to develop leadership across global contexts, and the strength of relationships creates the sense of community. Within that community, much is possible. The outcomes have and will document the power of these intentional experiences.

Nursing needs leadership mentoring to provide connections for the next generation of nurses to create environments for a culture of health, safety, and well-being. We need mentoring to teach how to develop collegiality in a stressful profession. Nursing can welcome and nurture its own novice nurses into future leadership roles. Global leadership means not only connecting through global relationships but also making a difference across the spectrum of nursing activity. From frontline clinical practice, to nursing organizational leadership, to health policy development, leadership mentoring means engaging nursing voice. It means investing the time and talent to nurture and teach leadership in new ways with the next generation. Seeking out opportunities for leadership mentoring is the first step! 


\section{References}

1. Hodgson AK, Scanlan JM. A concept analysis of mentoring in nursing leadership. Open Journal of Nursing. 2013;3:38494. DOI: https://doi.org/10.4236/ojn.2013.35052

2. Cardiff S, McCormack B, McCance T. Person-centred leadership: A relational approach to leadership derived through action research. Journal of Clinical Nursing. 2018;27:15-6. DOI https://doi.org/10.1111/jocn.14492

3. Morin K, Small L, Spatz DL, Solomon J, Lessard L, Leng SW. Preparing leaders in maternal-child health nursing. JOGNN: Journal of Obstetric, Gynecologic \& Neonatal Nursing. 2015;44(5):633-643. DOI: https://doi.org/10.1111/15526909.12730

4. Buckner EB, Anderson DJ, Garzon NA, Lai CK, Hafsteinsdóttir TB, Roshan R. Perspectives on global nursing leadership: International experiences from the field. International Nursing Review. 2014 Dec;61(4):463-471.

5. Buckner EB, Lai C. Symposium: Global Leadership Mentoring Community: Online STTI Community of Interest for Mentoring Emerging Global Nurse Leaders. Sigma Theta Tau International's 44th Biennial Convention [Internet]; 2017 Oct 28-Nov 1; Indianapolis, Indiana, USA. Available from: http://hdl.handle.net/10755/623038

6. Buckner EB, Lai C, Welk D. Symposium: Global Leadership Mentoring Community (GLMC): Expanding and Focusing in Cohort 2. Sigma Theta Tau International's 45th Biennial Convention [Internet]; 2019 Nov 16-20; Washington, D.C., USA. Available from: http://hdl.handle.net/10755/18948 